\title{
Abundance of Shrimp (Penaeus Monodon) Post Larvae (PL) and to Quantify the Damage of Different Aquatic Fauna during Shrimp PL Collection in Mongla Tidal River (Rampal), Bagerhat
}

\author{
J. Ferdousy, M. S. Islam*, N. Begum \\ Department of Coastal and Marine Fisheries, Faculty of Fisheries, Sylhet Agricultural University, \\ Sylhet-3100, Bangladesh
}

Received 10 June 2016, accepted in final revised form 19 September 2016

\begin{abstract}
The study was conducted in Mongla tidal river (Rampal) of Bagerhat district from November 2014 to October 2015 to assess the abundance of black tiger shrimp (Penaeus monodon) post larvae (PL) and to quantify the damage of different aquatic fauna during collection of $P$. monodon PL. Insignificant variation in water temperature, $\mathrm{pH}$, salinity and hardness were found but salinity and hardness showed great fluctuation during the study period. On average 6.3 million of $P$. monodon PL were collected annually from the studied area and around 0.16 million man days/year were estimated to be involved in shrimp PL collection activities. It was found that about 412 other shrimp larvae, 391 fin fishes and 1696 other macrozooplankton were killed during the period of collection for only one PL of P. monodon. It was also calculated from the present study that about 29,874 million of other shrimp species, fin fishes and macrozooplankton were destroyed annually by the shrimp seed harvesting process in Mongla river. The study implies that present seed collection practice caused severe damage of other valuable aquatic fauna, which directly affect the biodiversity of tidal waters, natural productivity, improvement of mother stock and environment friendly of coastal and marine water.
\end{abstract}

Keywords: P. monodon post larvae; Quantify; Indiscriminate damage; Aquatic fauna; Tidal river Mongla.

(C) 2017 JSR Publications. ISSN: 2070-0237 (Print); 2070-0245 (Online). All rights reserved. doi: http://dx.doi.org/10.3329/jsr.v9i1.28180 J. Sci. Res. 9 (1), 87-95 (2017)

\section{Introduction}

Shrimp, the non-piscine fisheries organism is the most precious fishery commodity of the country. The culture of shrimp in the coastal zone is a major export earning activity for Bangladesh. This culture was started in the coastal belt during the early 1980s to supply shrimp in the international markets and earn foreign currencies [1]. The Government and private sector intensified efforts to increase export earnings from this sector. This industry was initially dependent on natural sources for seed supply [2]. Though a few shrimp post

\footnotetext{
* Corresponding author: islamms2011@yahoo.com
} 
larvae (PL) hatcheries have been established in shrimp farming region to produce seed and meet the growing demand for PL, supply is still insufficient to meet industry requirements. As a result, people are collecting PL from natural stock, which causes destruction of huge number of fry of different fish species and other aquatic fauna. Due to this practice the wild fish and shrimp stock might be affected [3]. Farmers think that wild PL of shrimp to be of excellent quality than hatchery produced shrimp PL. Due to high demand, low investment and lucrative business of P. monodon PL, it is encouraged thousands of resource poor people of the coastal areas to be engaged in shrimp seed collection. Wild PL collection has given employment opportunity for thousands of coastal landless and unemployed people [4-6]. In Bangladesh more than 0.42 million people are involved in shrimp seed collection activities [7].

On the other hand, wild PL fishing has assumed a notorious impact on coastal biodiversity [8-11]. It has been reported that around 1650 larvae of other shrimp species, 1562 fin fishes and 6787 other macrozoplankton were cruelly damaged at the time of collection just for single PL of P. monodon in the Mongla river (Mongla), Bagerhat [12], which is a great threat to the biodiversity. Thousands of rural poor are involved in shrimp PL collection in the tidal rivers and along the coastal belt of Bangladesh as part of their livelihood.

Shrimp PL collection is a regular activity in the Mongla river throughout the year. Generally, drag net, push net and set bag nets are mostly used in shrimp fry collection activities. The collector or other member of the family/group generally sort out and collect only the targeted P. monodon PL and the rest of the haul composed of other shrimp, macrozooplankton and fin-fish larvae, which are valueless to them is carelessly discarded on the dry shore. This causes serious loss of biodiversity and creates pollution in the coastal areas. In this way a huge number of precious aquatic organisms are destroyed by the seed harvester, which is alarming and also a threat to natural food cycle as well. Keeping these views in mind, the present year-round study was undertaken to assess the abundance and catch composition of the drag/push net used for collecting PL of $P$. monodon and to quantify the damage caused to different shrimp species, fin fishes and zooplankton larvae while collecting PL of tiger shrimp in the Mongla tidal river (Rampal), Bagerhat.

\section{Materials and Methods}

The samples were collected from three different sites/spots of Mongla river (Rampal) under Bagerhat district from November 2014 to October 2015 (Fig. 1). Sampling was done at monthly intervals using fine meshed $(1.0 \mathrm{~mm})$ nylon net with bamboo split frames (1.6 x $0.6 \mathrm{~m})$. Sample was taken in the course of full-moon and new-moon. The net was operated in the shallow water of the river against the current. Each hauling time was about 10 min. Two samples were collected at the time during low and high tides. Samples were immediately stored in plastic pot and preserved in 5\% neutralized formalin after collection for sorting shrimp PL, larvae of fin fishes and other organisms. Samples were brought into 
the laboratory for analysis and it was performed within two weeks from the date of collection. Penaeid shrimp larvae were identified up to species level following Muthu [13], and Motoh and Buri [14]. Macrozooplankters, other shrimp species and fin fishes were identified as major taxonomic groups following Fischer and Witchead [15], George [16], and Shafi and Quddush [17].

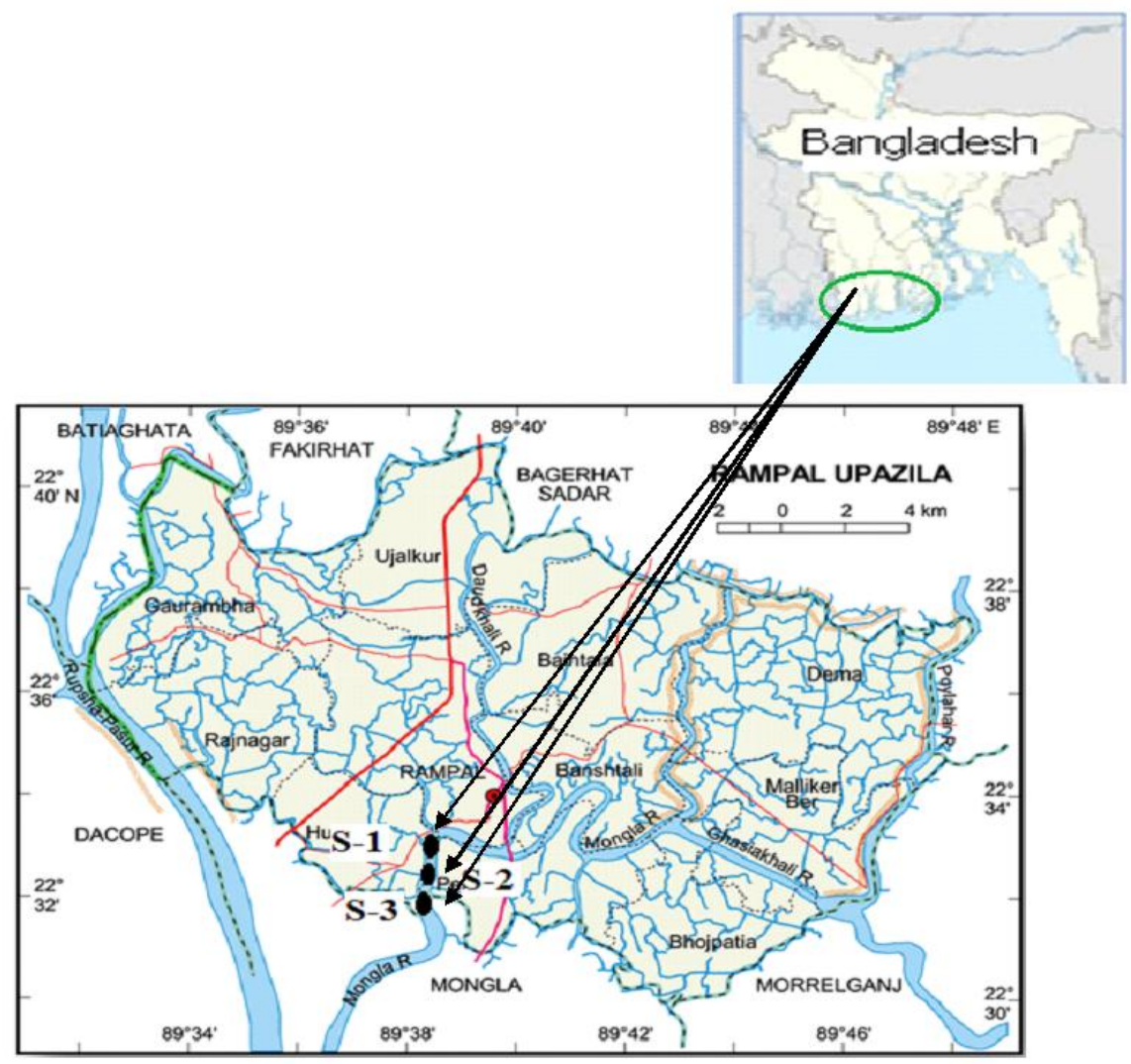

Fig. 1. Map of Rampal upazilla showing the location of sampling stations.

Salinity of water of each spot/area was recorded by a hand refractometer (ATAGO, Hand-Held Refractometer). Water temperature and $\mathrm{pH}$ were measured by alcohol thermometer and $\mathrm{pH}$ meter, respectively. Total hardness of water was determined titrimetrically using a standard solution of EDTA-0.800 M and Manver 2.

\section{Results and Discussion}

Monthly mean values of water temperature, salinity, $\mathrm{pH}$ and total hardness are presented in Fig. 2. There was no significant variation in water temperature but a wide fluctuation in 
salinity was found in all the sites. The highest temperature $\left(33.1^{\circ} \mathrm{C}\right)$ was recorded in September and the lowest $\left(22.0^{\circ} \mathrm{C}\right)$ in February. This observation is almost similar with the observation made by Islam et al. $[9,12]$ who recorded temperature ranging from 19.4 to $32.7^{\circ} \mathrm{C}$ and 21.5 to $31.7^{\circ} \mathrm{C}$ in Mongla river, Bagerhat and in Andermanik river as well as Kuakata coast in Patuakhali, respectively.

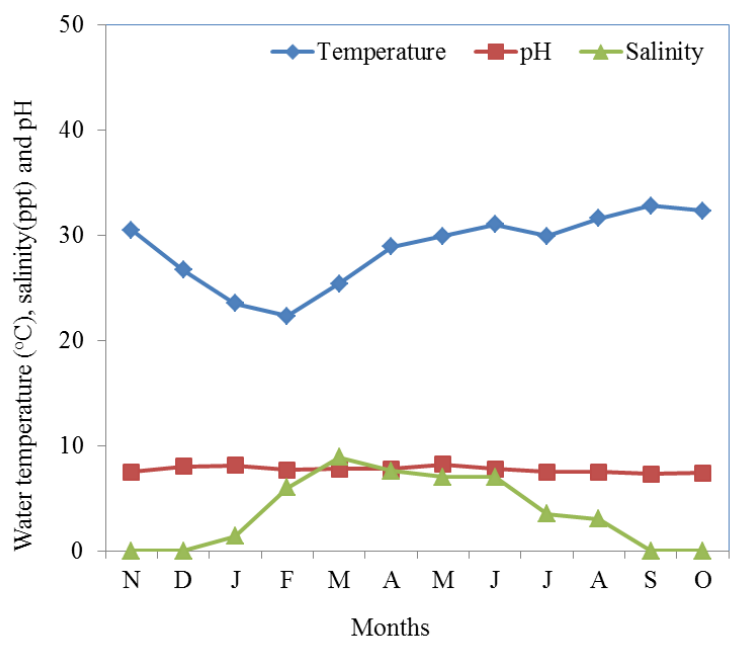

Fig. 2. Monthly fluctuation of water temperature $\left({ }^{\circ} \mathrm{C}\right)$, salinity (ppt) and $\mathrm{pH}$ in the river of Mongla.

Water salinity ranged from 0.0 to 13.5 , which is related to the findings of Islam et al. [12] who recorded salinity of 0.0 to $12.5 \mathrm{ppt}$ from the tidal water in Mongla river (Mongla). The highest salinity (13.5 ppt) was recorded in March at all the sites. Salinity was gradually decreased after the month of June and it declined to zero ppt from September to December, which might be due to monsoon effect, run-off, land drainage and heavy shower, which was found to increase during post-monsoon with the onset of dry season.

The range of $\mathrm{pH}$ value in the present study was 6.9-8.4. The highest value (8.4) of $\mathrm{pH}$ was recorded in May and the lowest (6.9) was recorded in August. This observation is agreed with the observation made by Islam et al. [12] who recorded $\mathrm{pH}$ ranging from 6.8 to 8.2 in Mongla river, Bagerhat. The values of total hardness ranged from 166.2-1252.0 $\mathrm{mg} / \mathrm{L}$ was found to coincide with the findings of Islam et al. [1] who reported hardness values ranging from 162-1350 mg/L Mongla river (Rampal), Bagerhat.

Monthly distribution (individuals/unit effort) data of P. monodon PL, larvae of other shrimps, fin-fishes and other macrozooplankton of the surveyed waterbodies during the study period has been depicted in Table 1. Data in Table 1 clearly showed that during the period of August to October, P. monodon PL was entirely absent in all the sites while salinity was moderately lower or zero ppt. The larvae of $P$. monodon were very rarely available during February to June though salinity gradually increased. On the other hand, 
abundance of other shrimp species was found to increase during the month of August to February and maximum was recorded in September through January and February in all the sites. There was no uniform pattern in distribution of both fin fishes and zooplankton. Their abundance also fluctuated from one month to another month. During post monsoon period, comparatively higher amount of fin fishes and macrozooplankton were observed than the other part of the year. This result is in agreement with the results of Islam et al. [9,12] and Rahman et al. [17] where the authors implied that lower salinity and temperature are probably the key factors influencing greatly the larval distribution of aquatic fauna.

Table 1. Monthly distribution (individual/unit effort) ${ }^{*}$ of Penaeus monodon PL, other shrimps, fin fishes and other macrozooplankton of the Mongla river, (Rampal).

\begin{tabular}{|c|c|c|c|c|c|c|c|c|c|c|c|c|c|c|}
\hline \multirow{3}{*}{ Major Groups } & \multirow{2}{*}{\multicolumn{12}{|c|}{ Months }} & \multirow{3}{*}{$\begin{array}{l}\text { Yearly } \\
\text { Total }\end{array}$} & \multirow{3}{*}{$\%$} \\
\hline & & & & & & & & & & & & & & \\
\hline & $\mathrm{N}$ & $\mathrm{D}$ & $\mathbf{J}$ & $\mathrm{F}$ & $\mathrm{M}$ & A & M & $\mathrm{J}$ & $\mathrm{J}$ & A & $\mathrm{S}$ & $\mathrm{O}$ & & \\
\hline \multicolumn{15}{|c|}{ Mongla river ( Spot 1 ) } \\
\hline P. monodon $\mathrm{PL}$ & 1 & 0 & 0 & 1 & 1 & 0 & 0 & 1 & 1 & 0 & 0 & 0 & 5 & 0.06 \\
\hline Other shrimps & 137 & 88 & 195 & 192 & 80 & 100 & 155 & 79 & 64 & 163 & 285 & 95 & 1633 & 18.27 \\
\hline Fin fishes & 149 & 160 & 187 & 163 & 88 & 65 & 18 & 28 & 35 & 55 & 250 & 295 & 1493 & 16.71 \\
\hline Other & 155 & 517 & 497 & 598 & 160 & 237 & 390 & 478 & 854 & 1005 & 299 & 615 & 5805 & 64.96 \\
\hline \multicolumn{15}{|c|}{ macrozooplankton } \\
\hline Total & 442 & 765 & 879 & 954 & 329 & 402 & 563 & 586 & 954 & 1223 & 834 & 1005 & 8936 & 100.00 \\
\hline \multicolumn{15}{|c|}{ Mongla river ( Spot 2) } \\
\hline P. monodon PL & 1 & 0 & 0 & 1 & 0 & 0 & 0 & 1 & 0 & 0 & 0 & 0 & 3 & 0.03 \\
\hline Other shrimps & 140 & 103 & 89 & 215 & 80 & 88 & 167 & 66 & 75 & 160 & 299 & 87 & 1558 & 15.42 \\
\hline Fin fishes & 169 & 145 & 209 & 165 & 71 & 85 & 15 & 47 & 25 & 71 & 257 & 267 & 1526 & 15.10 \\
\hline Other & 217 & 548 & 518 & 585 & 233 & 211 & 425 & 507 & 790 & 1399 & 948 & 637 & 7018 & 69.45 \\
\hline \multicolumn{15}{|l|}{ macrozooplankton } \\
\hline Total & 527 & 796 & 816 & 966 & 384 & 373 & 607 & 621 & 890 & 1630 & 1504 & 991 & 10105 & 100.00 \\
\hline \multicolumn{15}{|c|}{ Mongla river ( Spot 3) } \\
\hline P. monodon PL & 0 & 1 & 0 & 0 & 1 & 1 & 0 & 0 & 1 & 0 & 0 & 0 & 4 & 0.04 \\
\hline Other shrimps & 140 & 89 & 238 & 217 & 130 & 102 & 140 & 75 & 80 & 175 & 265 & 100 & 1751 & 16.02 \\
\hline Fin fishes & 179 & 185 & 225 & 202 & 93 & 89 & 25 & 37 & 35 & 64 & 248 & 288 & 1670 & 15.27 \\
\hline Other & 237 & 509 & 590 & 630 & 245 & 283 & 435 & 539 & 898 & 1519 & 968 & 655 & 7508 & 68.67 \\
\hline \multicolumn{15}{|l|}{ macrozooplankton } \\
\hline Total & 556 & 784 & 1053 & 1049 & 469 & 475 & 600 & 651 & 1014 & 1758 & 1481 & 1043 & 10933 & 100.00 \\
\hline
\end{tabular}

* Operating a push net $(1.6 \times 0.6 \mathrm{~m})$ for about 10 minutes taken as a unit effort.

Post larvae of $P$. monodon were found to occupy very small portion in the total annual catch composition such as $0.06,0.03$ and $0.04 \%$ at three sites in Mongla river (Rampal), respectively. Islam et al. [12] reported that the annual catch composition of $P$. monodon was $0.02,0.01$ and $0.01 \%$, respectively at three sites in Mongla river (Mongla) which is slightly lower than the present findings. Juveniles of other shrimp species $(P$. indicus, Metapenaeus monoceros, M. brevicornis, Palaemon styliferus, Macrobrachium rosenbergii, $M$. villosimanus, $M$. dyanus, $M$. dolichodactylus and $M$. rude, etc.) exerted $18.27 \%$ in spot $1,15.42 \%$ in spot 2 and $16.02 \%$ in spot 3 of Mongla river which is almost similar with the findings of Islam et al. [12] who reported the annual catch composition of other shrimp species of $18.34 \%, 15.39 \%$ and $16.01 \%$, respectively in three spots in 
Mongla river (Mongla). Larvae of fin fishes (Liza parsia, L. tade, Rhinomugil corsula, Lates calcarifer, Setipina phasa,Tenualosa ilisha, Pangasius pangasius, Glossogobius spp., Puntius spp., and Mystus spp.) formed 16.71, 15.10 and $15.27 \%$ of the total catch in spot 1, spot 2 and spot 3, respectively. Islam et al. [12] stated that the larvae of fin fishes at three spots of Mongla river (Mongla) were 16.70, 15.09 and 15.23\%, respectively. Islam et al. [1] also reported that the yearly catch composition of fin fish larvae in Mongla river at Mongla and Rampal part was 15.40 and $18.40 \%$, respectively. These findings are coincided with the findings of present study. Macrozooplankton (Acetes sp., Mysids, Isopods, Copepod, Alima, Crab larvae, etc.) showed higher density of 64.96, 69.45 and $68.67 \%$ in three sites of Mongla river, respectively. Islam et al. [1, 12] reported that the total annual catch composition of macrozooplankton was recorded to be 64.94, 69.51 and $68.75 \%$ at three sites of Mongla river (Mongla), respectively and 58.80\% in Mongla river (Rampal). Mahmood [18] stated that higher density of zooplankton $(98.30 \%)$ was found in Chakaria Sundarbans followed by Satkhira (97.72\%) and Khepupara (97.53\%). Moreover, other shrimps and fin fishes occupied only about $2 \%$ of the zooplankton community and shrimp (P. monodon) PL alone contributed a very small quantity to the total annual catch (0.7\% in Chakaria and Khepupara, and $1.2 \%$ in Satkhira). Islam et al. [9] reported that zooplankton recorded in Andermanik river of Patuakhali (53.51\%) and Ichamati river (93.19\%) as well as Kholpatua river $(96.56 \%)$ of Satkhira district was also higher than fin fishes and other shrimps. Other shrimps and fin fishes secured 40.60 and $5.28 \%$, respectively in Patuakhali Andermanik river. But these were 5.18 and $1.57 \%$ in Ichamati river, and 9.84 and $0.92 \%$ in Kholpatua river, Satkhira, respectively. PL of shrimp $(P$. monodon) alone scored the minimal number in both Patuakhali $(0.61 \%)$ and Satkhira $(0.06$ and $0.05 \%)$ region, which are more or less similar with the present findings.

The catch composition and extent of damage caused to macrozooplankton and other aquatic organisms as a result of heartlessly harvesting of $P$. monodon PL are presented in Tables 2 and 3. It was found that on average in the total relative abundance, P. monodon PL contributed only $0.04 \%$, other shrimp species $16.49 \%$, fin fishes $15.64 \%$ and other macrozooplankton $67.69 \%$. There are no remarkable differences in yearly catch composition in three spots of Mongla river (Rampal) (Table 1). But in the monthly distribution, higher amount of macrozooplankton was obtained in August in spot 3 (1519) followed by spot 2 (1399) and spot 1 (1005). The results of the study indicated that shrimp seed harvesters killed around 412 other shrimp species, 391 fin fishes and 1696 other macrozooplankton for catching a single PL of $P$. monodon. This finding is more or less coincided with the findings of Islam et al. [1] who obtained 569 other shrimp spp., 460 fin fishes and 1470 macrozooplankton were destroyed for catching only one PL of $P$. monodon in the Mongla river (Rampal). According to Mahmood [18] for catching only one PL of P. monodon, 14 other shrimp spp., 21 fin fishes and 1631 zooplanktons were killed in the Chakaria Sundarbans, Satkhira and Khepupara estuaries. The variations in the zooplankton population with the present findings might be due to difference in mesh size of the collection net. Mahmood [18] used a rectangular nylon net with smaller mesh size $(0.5 \mathrm{~mm})$. The mesh size of the net used in the present study was $1.0 \mathrm{~mm}$, which is not 
similar to that used by seed collectors. For this reason, smaller zooplankton and other species could escape through large mesh $(1.0 \mathrm{~mm})$ of net used in the present study. BFRI [19] reported that one PL of P. monodon was collected at the cost of 356 larvae of other shrimp species, fin fishes and macrozooplankton in the Bagerhat region in 1996. Islam et al. $[1,20]$ stated that for catching a single PL of P. monodon, the fry collectors destroyed 587 and 2499 larvae of other shrimps, fin fishes and macrozooplankton in Satkhira region and Monglariver (Rampal), respectively. The great loss of valuable different aquatic organisms was also reported by BOBP [21] and Khan et al. [22]. In addition to this, practice also causes death of huge number of $P$. monodon PL due to there is every possibility of destructive different appendages of PL and also become stress during collection and transportation, which eventually causes dead.

Table 2. Average catch composition (\%) of Penaeus monodon PL, other shrimp species, fin fishes and macrozooplankton in the Mongla river (Rampal).

\begin{tabular}{lccc}
\hline Major taxa & $\begin{array}{c}\text { Catch/unit effort } \\
(\text { No. })\end{array}$ & $\begin{array}{c}\text { Relative abundance } \\
(\%)\end{array}$ & $\begin{array}{c}\text { No. of other species damaged for } \\
\text { P.monodon } \text { PL collection }\end{array}$ \\
\hline Penaeus monodon PL & 4 & 0.04 & - \\
Other shrimp species & 1647 & 16.49 & 412 \\
Fin fishes & 1563 & 15.64 & 391 \\
Macrozooplankton & 6777 & 67.83 & 1696 \\
Total & 9991 & 100.00 & 2499 \\
\hline
\end{tabular}

Table 3. Comparative scenario of Penaeus monodon PL abundance and diversity of other organisms during the period of present study (November 2014-October 2015) and the previous study (May 2012April 2013).

\begin{tabular}{c|cc}
\hline \multirow{2}{*}{ Name of the species } & \multicolumn{2}{c}{$\begin{array}{c}\text { No. of the other species destroyed for catching single Penaeus } \\
\text { monodon PL }\end{array}$} \\
\cline { 2 - 3 } & $\begin{array}{c}\text { Present study (November 2014- } \\
\text { October 2015) }\end{array}$ & $\begin{array}{c}\text { Previous study (May 2012- } \\
\text { April 2013) }\end{array}$ \\
\hline Penaeus monodon PL & - & - \\
Other shrimp species & 412 & 1650 \\
Fin fishes & 391 & 1562 \\
Macrozooplankton & 1696 & 6787 \\
Total & 2499 & $9999^{*}$ \\
\hline
\end{tabular}

* The mesh size of the collecting net used in the present study and the previous study was $1.0 \mathrm{~mm}$ and $0.3 \mathrm{~mm}$, respectively. Comparatively higher number of other aquatic organisms is destroyed owing to small mesh size of the net.

Observation on the number of seed collectors $/ \mathrm{km}$, length of the river, number of boat and hour of appointment reveals that 0.16 million man days/year were involved in shrimp seed collection activities in Bagerhat district. This finding is closely associated to Islam et al. [12], who revealed that 0.18 million man days/year were engaged in shrimp seed collection activities in Mongla river (Mongla), Bagerhat. Funegaard [23] reported that about 20,000-25,000 people were engaged in shrimp fry collection in Satkhira district while according to Chowdhury [24] about 75,000 fry collectors were found only in Satkhira district. It was observed that about 6.3 million of P. monodon PL were collected in Mongla river (Rampal) in 2014-2015. Islam et al. [20] reported that about 11.60 million 
P. monodon PL were collected in Satkhira in 1996 and it was 18.0 million in 1992 [19], which are higher than the present findings. From the present study, it was also ascertained that 29874 million of other shrimp species, fin fishes and macrozooplankton were destroyed annually by the shrimp seed collectors in Bagerhat Mongla river (Rampal) is closely related to the findings of Islam et al. [12] who estimated 29988 million of other aquatic organisms destroyed annually by the shrimp seed collection activities in Mongla river (Mongla), Bagerhat but it is much higher than the findings of Islam et al. [20] who estimated 6809 million of other aquatic organisms in Satkhira. This is very much alarming for the biodiversity of coastal waters. The severe impact of shrimp seed collection activities drastically reduced the availability of $P$. monodon from 2,000 shrimp fry/net/day [23] to only 200 fry/net/day [25] in Satkhira district. So the findings of the above mentioned studies and also the present study reveal that there has been a trend of gradual decreasing in the abundance of other shrimps, fin fishes and other zooplankton larvae in neritic and offshore waters. This might be connected with over fishing with smaller mesh sized nylon nets and indiscriminate killing of zooplankton and other shrimps that hinder the normal recruitment pattern to the original mother stock. Therefore, appropriate steps should immediately be taken to stop such indiscriminate killing of juvenile fish and shell fishes during collection of shrimp PL and to grow awareness among the seed collectors to release back the unwanted organisms into the waterbodies without any damage. These initiatives would help to preserve the biodiversity of aquatic fauna and to save environment friendly of tidal waterbodies.

\section{References}

1. M. S. Islam, S. U. Ahmed, and M. S. A. Khan, Bangladesh Fisheries Research Institute, Brackishwater Station (Paikgacha, Khulna, Bangladesh, 2001) pp. 93.

2. G. Khan, Fourth Fisheries Project 2002, 69 pp.

3. M. G. Khan and M. A. Latif, Bay of Bengal Program (Madras, India, 1997) BOBP/REP/74, 5577.

4. C. L. Angell, Bay of Bengal News 3, 6 (1990).

5. Fish and Agriculture Organization (FAO)/ Network of Aquaculture Centers in Asia-Pacific (NACA) (Bangkok, Thailand, 1995).

6. M. S. Islam and M. A.Wahab, Hydrobiologia 542, 165 (2005). http://dx.doi.org/10.1007/s10750-004-0756-y

7. USAID (The United States Agency for International Development) Development and Training Services, Inc. (Arlington, VA 22203, 93 (2006).

8. J. H. Primavera, Tropical mariculture (Academic Press, London, 1998) pp. 257-289 http://dx.doi.org/10.1016/B978-012210845-7/50008-8

9. M. S. Islam, M. M. Islam, and S. U. Ahmed, Bang. J. Fish. 3(1), 107 (1999a).

10. M. E. Hoq, M. N. Islam, M. Kamal, and M. A. Wahab, Hydrobiologia 457, 97 (2001). http://dx.doi.org/10.1023/A:1012266623308

11. A. Bhattacharya and S. K. Sarkar, AMBIO 32, 70 (2003). http://dx.doi.org/10.1579/0044-7447-32.1.70

12. M. S. Islam, M. M. Rahman, K. K. U. Ahmed, M. M. Hossain, P. P. Barman, and M. J. Islam. J. Asiat. Soc. Bangladesh, Sci. 41(1), 105 (2015).

13. M. S. Muthu, Marine Prawn Culture, Part-1: Larvae Development of Indian Penaeid Prawns, CMFRI Bull. 28, 86 (1978). 
14. H. Motoh and P. Buri. Aquaculture Dept. SEAFDEC, Trigbaun, Iliolio, Philippines, Res. Rep. 4(2), 15 (1980).

15. W. Fischer, P. J. P. Witchead (eds.) Eastern Indian Ocean Fisheries Area 57 and Western Centran Pacific Area Pag-Var. I-IV (1974).

16. M. J. George, Prawn Fisheries of India-II. Cent. Mar. Fish. Res. Inst. 14, 5(1969).

17. M. M. A. Quddush and M. Shafi, Fisheries Resources of Bay of Bengal, (Bangla Academy, Dhaka, Bangladesh, 1998) pp. 1-476.

18. S. L. Rahman, M. M. Islam, M. E. Hoq, G. C. Haldar, and S. U. Ahmed, Bang. J. Fish. Res. 1(1), 41 (1997).

19. N. Mahmood - Proc. Seventh Zool. Conf. (Bangladesh, 1990) pp. 87.

20. Bangladesh Fisheries Research Institute (BFRI), (Mymensingh, Bangladesh, unpublished, 1996) pp. 65.

21. M. S. Islam, M. M. Islam, and S. U. Ahmed, Bangladesh J. Fish. 22(2), 35 (1999b).

22. BOBP (Bay of Bengal Program), Bay of Bengal News, Madras, India 47, 1 (1992).

23. M. G. Khan, M. S. Islam, Z. A. Chowdhury, and S. C. Paul, DoF, Bangladesh 1 (1988).

24. P. Funegaard, Bay of Bengal News, 22, 2 (1986.).

25. M. R. Chowdhury, BAAS, Bangladesh, 20 (1990).

26. M. M. Alam, M. Sc. Thesis, Institute of Marine Science, University of Chittagong, Bangladesh (1990) pp. 45. 